Prepared in cooperation with the U.S. Environmental Protection Agency

\title{
Groundwater Flux and Nutrient Loading in the Northeast Section of Bear Lake, Muskegon County, Michigan, 2015
}

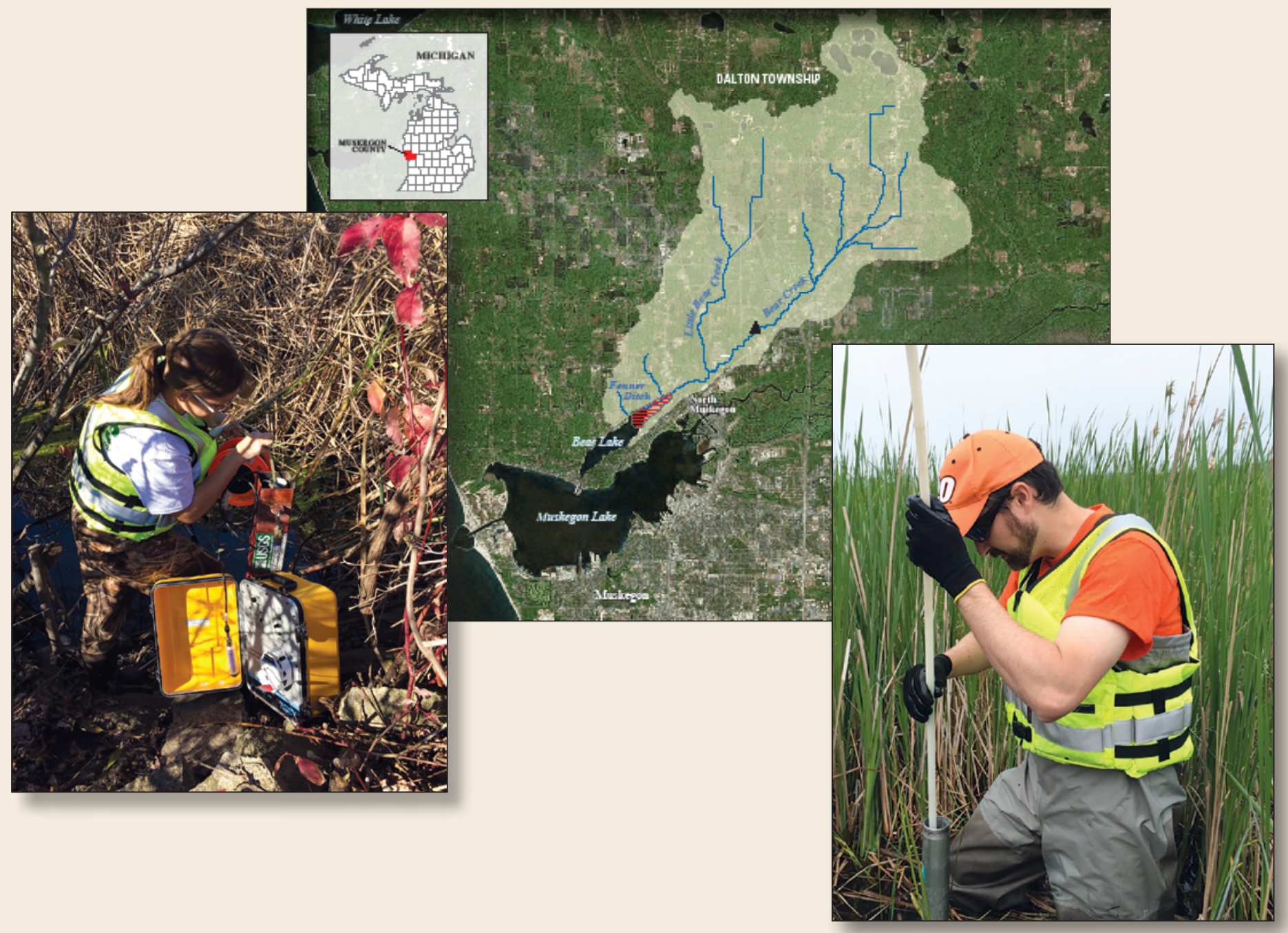

Scientific Investigations Report 2017-5092 
Cover image center. Map showing the Bear Creek watershed and general sampling location.

Cover photograph, left. U.S. Geological Survey staff taking discrete water-level measurements in preparation for nutrient sample collection, Bear Lake Muskegon County, Michigan. Photograph by Alex Totten.

Cover photograph, right. U.S. Geological Survey employee installing shallow groundwater wells on northeast end of Bear Lake, Muskegon County, Michigan. Photograph by Joe Duris. 


\section{Groundwater Flux and Nutrient Loading in the Northeast Section of Bear Lake, Muskegon County, Michigan, 2015}

By Alexander R. Totten, Jessica A. Maurer, and Joseph W. Duris

Prepared in cooperation with the U.S. Environmental Protection Agency

Scientific Investigations Report 2017-5092 


\title{
U.S. Department of the Interior \\ RYAN K. ZINKE, Secretary
}

\section{U.S. Geological Survey William H. Werkheiser, Acting Director}

\author{
U.S. Geological Survey, Reston, Virginia: 2017
}

For more information on the USGS - the Federal source for science about the Earth, its natural and living resources, natural hazards, and the environment—visit https://www.usgs.gov or call 1-888-ASK-USGS.

For an overview of USGS information products, including maps, imagery, and publications, visit https://store.usgs.gov.

Any use of trade, firm, or product names is for descriptive purposes only and does not imply endorsement by the U.S. Government.

Although this information product, for the most part, is in the public domain, it also may contain copyrighted materials as noted in the text. Permission to reproduce copyrighted items must be secured from the copyright owner.

Suggested citation:

Totten, A.R., Maurer, J.A., and Duris, J.W., 2017, Groundwater flux and nutrient loading in the northeast section of Bear Lake, Muskegon County, Michigan, 2015: U.S. Geological Survey Scientific Investigations Report 2017-5092, 16 p., https://doi.org/10.3133/sir20175092.

ISSN 2328-0328 (online) 


\section{Contents}

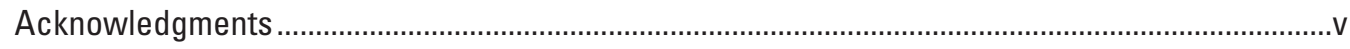

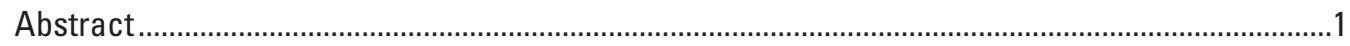

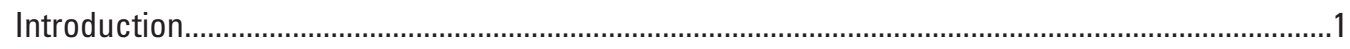

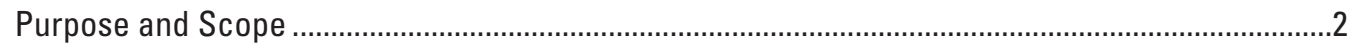

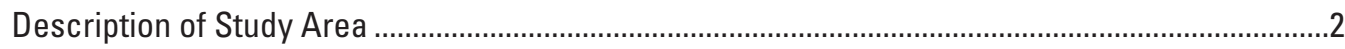

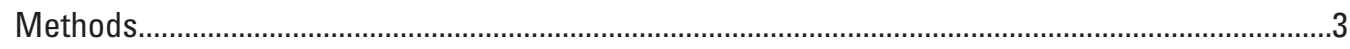

Water-Level Monitoring Equipment Installation ........................................................................4

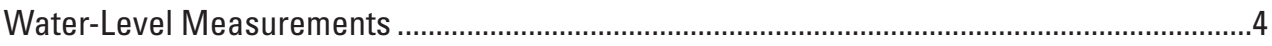

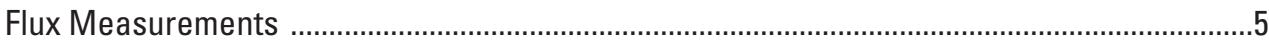

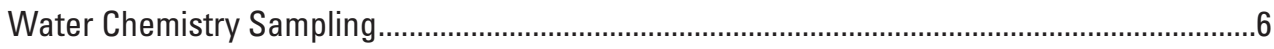

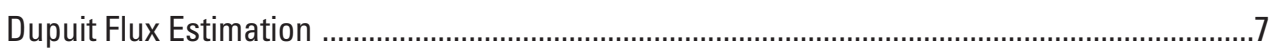

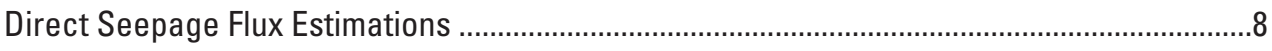

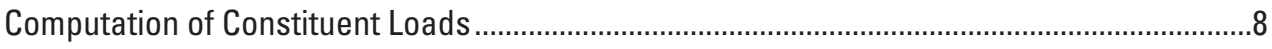

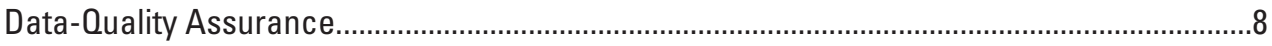

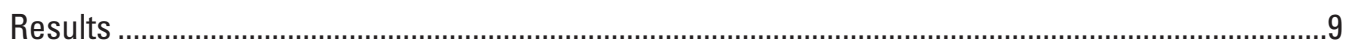

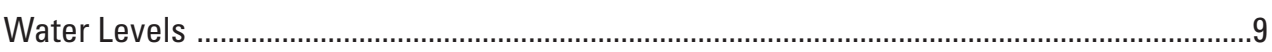

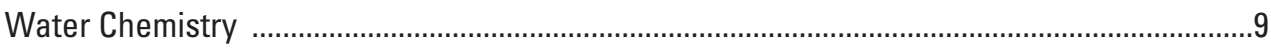

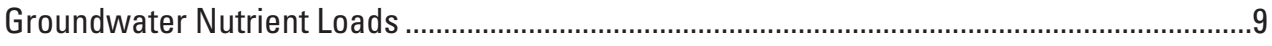

Constituent Concentration Comparison .................................................................................. 12

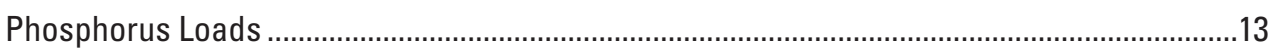

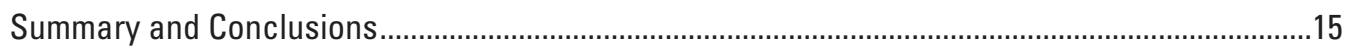

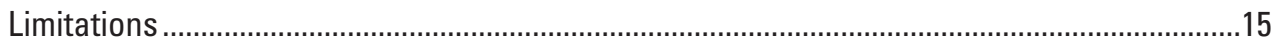

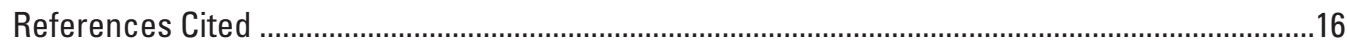

\section{Figures}

1. Map showing the Bear Creek watershed and general sampling location .......................2

2. Map showing sample locations indicating discrete and continuous water-level measurements....................................................................................................................

3. Diagram of Dupuit equation variable reference................................................................

4. Graph showing continuous water levels in feet above North American

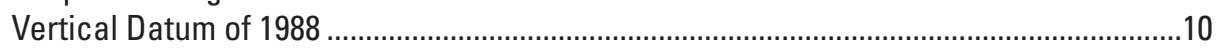

5. Pie diagrams showing phosphorus load of Bear Lake based on Michigan Department of Environmental Quality initial estimations and updated estimations by Annis Water Resource Institute and U.S. Geological Survey . 


\section{Tables}

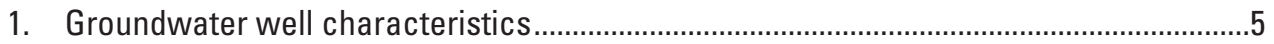

2. Surface water site information.........................................................................................

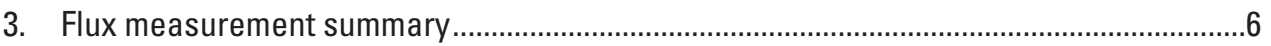

4. Summary statistics of constituent concentrations by sampling site ...............................11

5. Method comparison of the total annual flux (cubic feet per year) and annual constituent load (pounds per year) .....................................................................12

6. Comparison of study observations with previously reported national and regional observations

\section{Conversion Factors}

International System of Units to U.S. customary units

\begin{tabular}{lll}
\hline \multicolumn{1}{c}{ Multiply } & \multicolumn{1}{c}{ By } & To obtain \\
\hline & Length & \\
\hline centimeter $(\mathrm{cm})$ & 0.3937 & inch (in.) \\
millimeter (mm) & 0.03937 & inch (in.) \\
meter (m) & 3.281 & foot (ft) \\
kilometer $(\mathrm{km})$ & 0.6214 & mile (mi) \\
meter (m) & 1.094 & yard (yd) \\
& Volume & \\
liter (L) & 0.2642 & gallon (gal) \\
\hline
\end{tabular}

U.S. customary units to International System of Units

\begin{tabular}{lcc}
\hline \multicolumn{1}{c}{ Multiply } & By & To obtain \\
\hline mile (mi) & Length & kilometer $(\mathrm{km})$ \\
mile, nautical (nmi) & 1.609 & kilometer $(\mathrm{km})$ \\
yard (yd) & 1.852 & meter $(\mathrm{m})$ \\
& 0.9144 & \\
acre & Area & square mile $\left(\mathrm{mi}^{2}\right)$ \\
& 0.0015 & \\
\hline cubic foot (ft $\left.{ }^{3}\right)$ & Volume & gallon $(\mathrm{gal})$ \\
\hline
\end{tabular}

Temperature in degrees Celsius $\left({ }^{\circ} \mathrm{C}\right)$ may be converted to degrees Fahrenheit $\left({ }^{\circ} \mathrm{F}\right)$ as follows:

${ }^{\circ} \mathrm{F}=\left(1.8 \times{ }^{\circ} \mathrm{C}\right)+32$.

Temperature in degrees Fahrenheit $\left({ }^{\circ} \mathrm{F}\right)$ may be converted to degrees Celsius $\left({ }^{\circ} \mathrm{C}\right)$ as follows:

${ }^{\circ} \mathrm{C}=\left({ }^{\circ} \mathrm{F}-32\right) / 1.8$. 


\section{Datum}

Vertical coordinate information is referenced to the North American Vertical Datum of 1988 (NAVD 88).

Horizontal coordinate information is referenced to the, North American Datum of 1983 (NAD 83).

Altitude, as used in this report, refers to distance above the vertical datum.

\section{Supplemental Information}

Concentrations of chemical constituents in water are given in milligrams per liter (mg/L).

\section{Abbreviations}

$\begin{array}{ll}\text { AOC } & \text { area of concern } \\ \text { AWRI } & \text { Annis Water Resource Institute } \\ \text { BUI } & \text { beneficial use impairment } \\ \text { EPA } & \text { U.S. Environmental Protection Agency } \\ \text { MDEO } & \text { Michigan Department of Environmental Quality } \\ \text { NAWQA } & \text { National Water-Quality Assessment } \\ \text { NWIS } & \text { National Water Information System } \\ \text { NWOL } & \text { National Water Quality Laboratory } \\ \text { ROS } & \text { Regression on Order Statistics } \\ \text { USGS } & \text { U.S. Geological Survey } \\ \text { WMSRDC } & \text { West Michigan Shoreline Regional Development Commission }\end{array}$

\section{Acknowledgments}

We would like to acknowledge our project partners including those in the U.S. Geological Survey (USGS) Michigan-Ohio Water Science Center (Lansing, Michigan), West Michigan Shoreline Regional Development Commission (WMSRDC), Annis Water Resources Institute, the U.S. Environmental Protection Agency, and all others who contributed to this project. For their exceptional support, we would like to specifically thank Kathy Evans, Program Manager; Roy Portenga, Landowner; Harold Closz, Landowner; and Christopher Hoard, Groundwater Specialist. 



\title{
Groundwater Flux and Nutrient Loading in the Northeast Section of Bear Lake, Muskegon County, Michigan, 2015
}

\author{
By Alexander R. Totten, Jessica A. Maurer, and Joseph W. Duris
}

\section{Abstract}

Bear Lake in North Muskegon, Michigan, is listed as part of the Muskegon Lake area of concern as designated by the U.S. Environmental Protection Agency. This area of concern was designated as a result of eutrophication and beneficial use impairments. On the northeast end of Bear Lake, two man-made retention ponds (Willbrandt Pond East and Willbrandt Pond West), formerly used for celery farming, may contribute nutrients to Bear Lake. Willbrandt Ponds (East and West) were previously muck fields that were actively used for celery farming from the early 1900s until 2002. The restoration and reconnection of the Willbrandt Ponds into Bear Lake prompted concerns of groundwater nutrient loading into Bear Lake. Studies done by the State of Michigan and Grand Valley State University revised initial internal phosphorus load estimates and indicated an imbalance in the phosphorus budget in Bear Lake. From June through November 2015, the U.S. Geological Survey (USGS) did an investigative study to quantify the load of nutrients from shallow groundwater around the Willbrandt Ponds in an effort to update the phosphorus budget to Bear Lake. Seven sampling locations were established, including five shallow groundwater wells and two surface-water sites, in the Willbrandt pond study area and Bear Lake. A total of 12 nutrient samples and discrete water-level measurements were collected from each site from June through November 2015. Continuous water-level data were recorded for both surface-water monitoring locations for the entire sampling period.

Water-level data indicated that Willbrandt Pond West had the highest average water-level elevation of all sites monitored, which indicated the general direction of flux is from Willbrandt Pond West to Bear Lake. Nutrient and chloride loading from Willbrandt Pond West to Bear Lake was calculated using two distinct methods: Dupuit and direct seepage methods. Shallow groundwater loading calculations were determined by using groundwater levels to first determine a flux of shallow groundwater, then nutrient concentrations to determine a load. It was determined that Willbrandt Pond East and Willbrandt Pond West contributed between 2 to 4 percent of the total annual phosphorus load to Bear Lake by way of shallow groundwater flow. Annual loads calculated for other constituents include orthophosphate (40-100 pounds per year [lb P/yr]), total nitrogen
(200-830 lb/yr), chloride (12,700-32,100 lb/yr), and ammonia (130-670 lb N/yr). Study results indicated that mean groundwater and surface-water nutrient concentrations calculated in this study were higher than reported Michigan statewide values. The data collected in this study allow understanding of groundwater nutrient loading into Bear Lake in an effort to help inform future restoration and management decisions.

\section{Introduction}

The Willbrandt Pond study area consists of two manmade earthen berm retention ponds (Willbrandt Pond East and Pond West) on the northeast end of Bear Lake in North Muskegon, Michigan, in Muskegon County (figs. 1 and 2). For nearly a century, Willbrandt Ponds East and West were used for celery farming, which included the use of nutrient-rich fertilizers (Smit and Steinman, 2014). After the termination of celery farming in 2002, the fields were converted to retention ponds and subsequent visible changes in water quality, including severe algal growth in both ponds, were reported by North Muskegon residents. Eutrophication became a problem in the ponds as a result of the nutrient-rich conditions. In 2008, Muskegon Lake became an area of concern (AOC) and was identified as having beneficial use impairments (BUI) for loss of fish and wildlife habitat (LeSage and Smith, 2008). Bear Lake is upstream from Muskegon Lake in the natural watershed and is associated with that AOC (fig. 1). A previous study done by the Michigan Department of Environmental Quality (MDEQ) in 2008 calculated the internal and external phosphorus loads to Bear Lake and determined that most of the phosphorus load was contributed by Bear Creek (MDEQ, 2008). In 2015, the Annis Water Resource Institute (AWRI) did a study on Bear Lake's internal phosphorus load and was able to more accurately calculate internal phosphorus loading (AWRI, 2015). The updated internal phosphorus load from AWRI is used throughout this report in conjunction with the total phosphorus load from MDEQ to create an accurate phosphorus load. From June through November 2015, the U.S. Geological Survey (USGS), in cooperation with U.S. Environmental Protection Agency (EPA), did a study to better understand groundwater nutrient loading into Bear Lake from the 


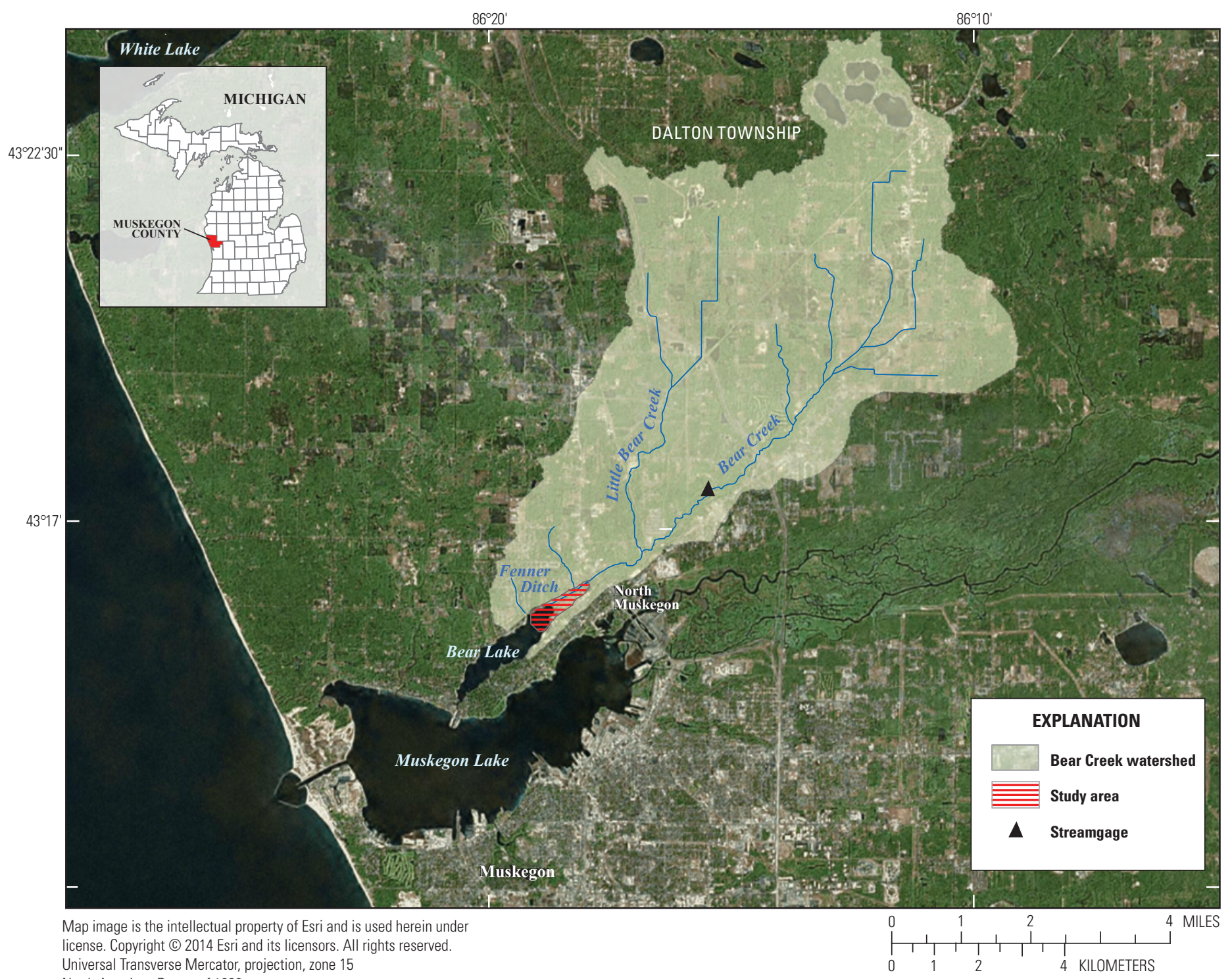

North American Datum of 1983

Lakes, streams, and catchments from National Hydrography Dataset

Watershed from the U.S. Geological Hydrography Dataset

Figure 1. Bear Creek watershed and general sampling location.

Willbrandt Ponds. Starting in 2016, earthen berms around both ponds were removed to return the ponds to natural wetland habitat. Understanding of nutrient dynamics associated with Willbrandt Ponds is important to understanding the potential response of Bear Lake to the removal of these berms.

\section{Purpose and Scope}

The data collected for this study refined the understanding of groundwater flux and nutrient loading into Bear Lake in an effort to help inform future restoration and management decisions. The objectives for this report are to (1) monitor water levels and groundwater flux direction; (2) determine annual flux and nutrient and chloride loading from shallow groundwater; and (3) compare groundwater and surface-water nutrient concentrations to previously published data.

\section{Description of Study Area}

This study was conducted in the northeast corner of Bear Lake (in and around the mouth of Bear Creek and the Willbrandt Ponds) in North Muskegon, Muskegon County, Mich. (fig. 1). The Bear Lake watershed drains approximately 30 square miles $\left(\mathrm{mi}^{2}\right)$, originates in Dalton Township, and terminates at the confluence of Bear Lake and Muskegon Lake in the City of North Muskegon (MDEQ, 2008). Bear Lake is a shallow (mean depth of 6.8 feet [ft]; maximum depth of $11.81 \mathrm{ft}$ ), wellmixed lake covering approximately $0.65 \mathrm{mi}^{2}$ confirmed by the AWRI (AWRI, 2015; MDEQ, 2008). The primary tributary flowing into Bear Lake is Bear Creek, with Fenner Ditch and two other minor unnamed tributaries directly draining to the lake (MDEQ, 2008). The entire area of Bear Lake is included in the Muskegon Lake AOC and frequently experiences eutrophication (AWRI, 2015; MDEQ, 2008). 


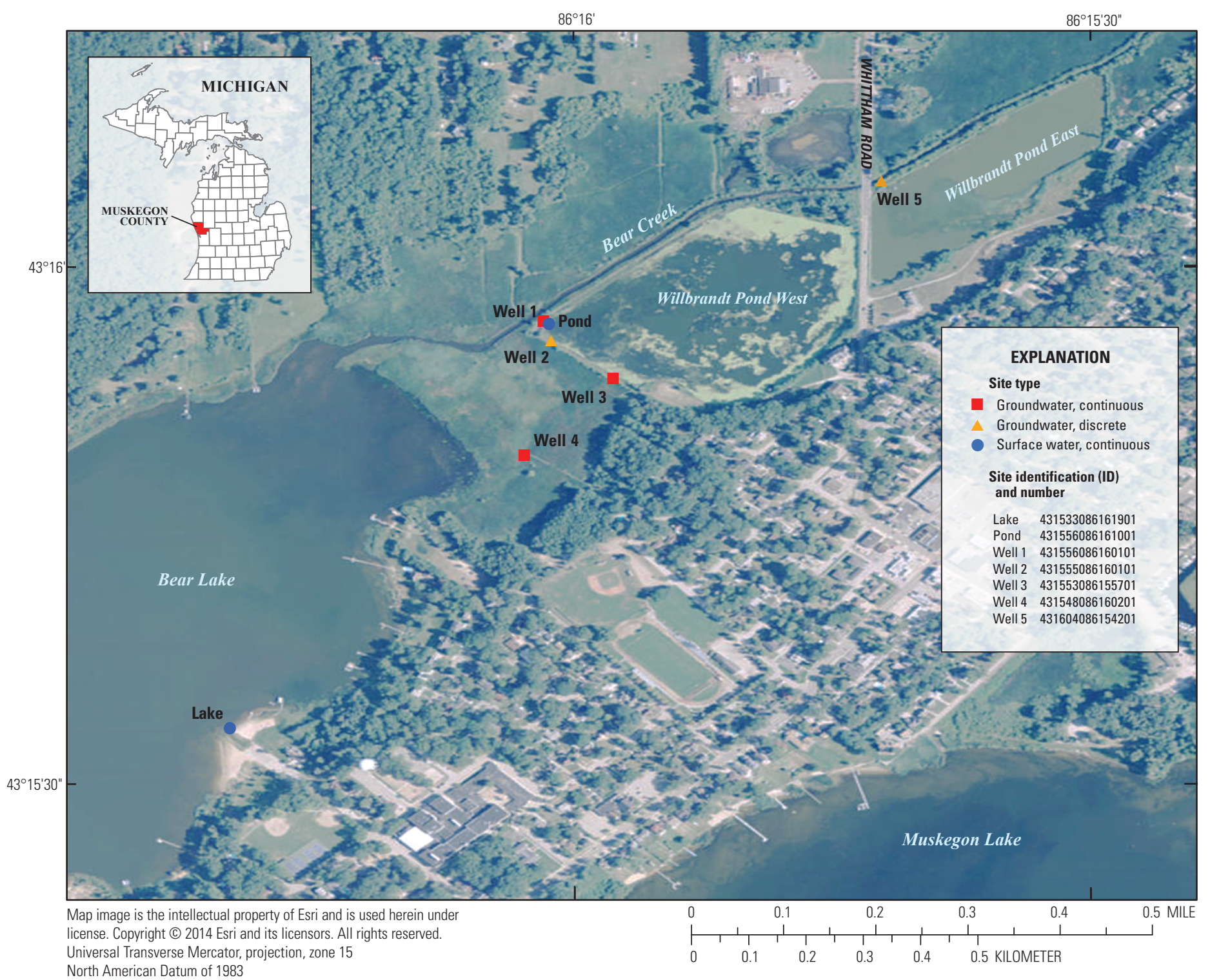

Figure 2. Sample locations indicating discrete and continuous water-level measurements.

The Willbrandt Ponds East and West occupy a total area of 40 acres and are bisected west to east by Whittham Road (Smit, 2014). Willbrandt Pond East and Willbrandt Pond West are named such based on their relative position to Whittham road (fig. 2). Bear Creek flows along the northern edge of both ponds and is separated from the ponds by a large earthen berm that was established to irrigate the fields for celery farming in the early 1900s (Smit, 2014). Willbrandt Pond East was actively being farmed until 1995, whereas Willbrandt Pond West was actively farmed until 2002 (Smit, 2014). Since that time, there has been no active farming or management of pond levels; however, there are several passive drains that discharge to Bear Creek when the pond levels rise to the height of the openings of the drains (Smit, 2014). The West pond is separated from Bear Lake on its western edge by another large earthen berm and by a small, 16.8-acre, vegetated marsh by a distance of approximately $6,560 \mathrm{ft}$, depending on the inundation of the marsh by Bear Lake.

\section{Methods}

USGS personnel collected groundwater levels and nutrient samples for nutrient analysis in shallow groundwater around the Willbrandt Pond East and Pond West. Surfacewater levels and water samples were also collected at Bear Lake and Willbrandt Pond West. In addition, groundwater flow direction was calculated using groundwater levels measured at Wells 1-5 (fig. 2). Groundwater seepage was directly measured using seepage meters and estimated based on water-level observations. Nutrient and chloride concentrations in the collected water samples were measured and those measurements were used in calculating loads. 


\section{Water-Level Monitoring Equipment Installation}

Five shallow groundwater monitoring wells were installed on June 9, 2015, around the Willbrandt Pond East and Pond West and near the mouth of Bear Creek. Wells were placed between the Willbrandt Pond East and Pond West and Bear Lake or Bear Creek to obtain samples to determine shallow groundwater nutrient concentrations in flux. Water levels were computed for each well to determine general direction of shallow groundwater flow and range of water elevations throughout the study. The maximum depth of the wells did not exceed $6 \mathrm{ft}$ and the wells were installed using a handheld sliding hammer. Characteristics for each groundwater well are provided in table 1 . Groundwater well installation techniques followed those published by Cunningham and Schalk (2011). Continuous water-level elevation monitoring equipment was installed in Well 1, Well 3, and Well 4 (fig. 1); all three wells were equipped with a pressure transducer, which recorded the water level and water temperature in the well every 15 minutes. Well 3 also was equipped with a barometric pressure sensor that recorded barometric pressure for water-level calculation every 15 minutes. These barometric data were used to calculate pressure-adjusted water levels in the surrounding wells (Cunningham and Schalk, 2011).

Surface-water site characteristics are provided in table 2. The location of each groundwater and surface-water monitoring location are presented in figure 1. Surface-water sampling sites were established on Bear Lake and Willbrandt Pond West (hereafter referred to as "Lake" and "Pond") to compare surface-water levels and groundwater levels. Water elevations computed by the pressure transducers in Bear Lake and Willbrandt Pond West were applied to the Dupuit equation to obtain shallow groundwater nutrient loads (Rosenberry 2008). Pressure transducers were installed in Willbrandt Pond West and Bear Lake, which recorded absolute pressure and temperature every 15 minutes. Surface-water levels were produced by compensating for atmospheric pressure fluctuations using the barometric logger. Pressure transducer software (Win-Situ 5 version 5.6.27.1) produced compensated water-level data using synchronized data files from the barometric logger and pressure transducer sites. Because of malfunctions in the pressure transducers from October 2015 to November 2015 barometric pressure data was taken from a local National Oceanic and Atmospheric Administration weather station in Muskegon, Mich. (NOAA, 2015), to compute surfacewater levels at Bear Lake and Willbrandt Pond West.

\section{Water-Level Measurements}

Discrete groundwater levels were made using an electrical tape and (or) steel tape at the time of each sampling event. Groundwater-level measurements were made before and after purging and sampling wells to compare with continuously recorded water-level data. Discrepancies in continuously recorded water-level data with the discrete water-level measurements plus or minus $0.02-\mathrm{ft}$ were corrected to match the discrete water level. All groundwater-level measurements were collected following guidelines described in Cunningham and Schalk (2011). Discrete surface-water-level measurements were made at Willbrandt Pond West and Bear Lake using a folding rule from an established measuring point to water surface. Similarly, discrepancies in continuously recorded water-level data with the

\section{U.S. Geological Survey employee installing shallow groundwater wells on northeast end of Bear Lake, Muskegon County, Michigan.}

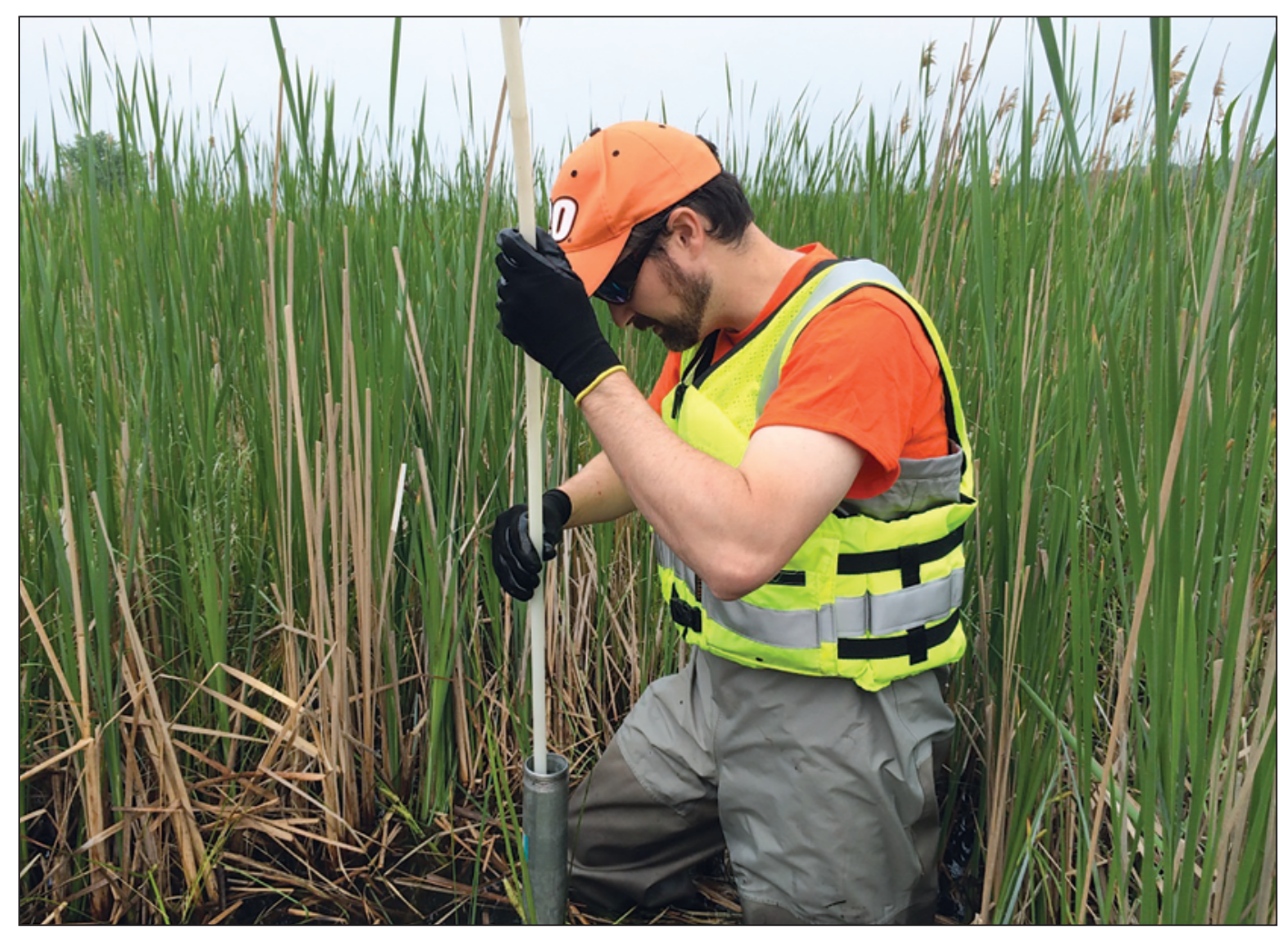


Table 1. Groundwater well characteristics.

[in., inch; ft, foot; NAVD 88, North American Vertical Datum of 1988]

\begin{tabular}{cccccccccc}
\hline $\begin{array}{c}\text { Well } \\
\text { name }\end{array}$ & $\begin{array}{c}\text { Site } \\
\text { number }\end{array}$ & $\begin{array}{c}\text { Date of } \\
\text { install }\end{array}$ & $\begin{array}{c}\text { Date of } \\
\text { transducer } \\
\text { installation }\end{array}$ & $\begin{array}{c}\text { Diameter } \\
\text { (in.) }\end{array}$ & $\begin{array}{c}\text { Screened } \\
\text { interval } \\
\text { open top (ft) }\end{array}$ & $\begin{array}{c}\text { Screened } \\
\text { interval } \\
\text { open } \\
\text { bottom (ft) }\end{array}$ & $\begin{array}{c}\text { Measuring } \\
\text { point (ft) }\end{array}$ & $\begin{array}{c}\text { Well } \\
\text { depth (ft) } \\
\text { elevation } \\
\text { (ft above } \\
\text { NAVD 88) }\end{array}$ \\
\hline Well 1 & 431556086160101 & $6 / 9 / 2015$ & $6 / 23 / 2015$ & 2 & 1.7 & 4.3 & 3.65 & 5 \\
\hline Well 2 & 431555086160101 & $6 / 9 / 2015$ & none & 2 & 2.43 & 5.03 & 2.92 & 5.73 & 580.55 \\
Well 3 & 431553086155701 & $6 / 9 / 2015$ & $6 / 16 / 2015$ & 2 & 2.35 & 4.95 & 3 & 5.65 & 579.75 \\
\hline Well 4 & 431548086160201 & $6 / 9 / 2015$ & $6 / 23 / 2015$ & 2 & 2.55 & 5.15 & 2.8 & 5.85 & 578.38 \\
\hline Well 5 & 431604086154201 & $6 / 9 / 2015$ & none & 2 & 1.23 & 3.83 & 4.12 & 4.53 & 578.88 \\
\hline
\end{tabular}

Table 2. Surface water site information.

[ft, foot; NAVD 88, North American Vertical Datum of 1988]

\begin{tabular}{lcccc}
\hline \multicolumn{1}{c}{$\begin{array}{c}\text { Surface water } \\
\text { site name }\end{array}$} & Site number & $\begin{array}{c}\text { Date of site } \\
\text { installation }\end{array}$ & $\begin{array}{c}\text { Measuring point } \\
\text { (ft above NAVD 88) }\end{array}$ & $\begin{array}{c}\text { Depth below } \\
\text { measuring point (ft) }\end{array}$ \\
\hline Bear Lake & 431533086161901 & $6 / 22 / 2015$ & 579.47 & 0.5 \\
Willbrandt Pond West & 431556086161001 & $6 / 22 / 2015$ & 579.73 & 0.5 \\
\hline
\end{tabular}

discrete water-level measurements plus or minus $0.02-\mathrm{ft}$ were corrected to match the discrete water level. Waterlevel data can be accessed from the USGS National Water Information System (NWIS) database (U.S. Geological Survey, 2017).

\section{Flux Measurements}

Five discrete seepage measurements were collected on October 6, 2015, along the berms of Willbrandt Pond East and Pond West in Bear Creek. These measurements were collected using a plastic 55-gallon half-barrel seepage meter to make a direct measurement of the flux of water across the sediment-water interface (Rosenberry and LaBaugh, 2008). A half-barrel drum was submerged into the surface water and positioned into the sediment to contain and measure the groundwater seepage that crosses the sediment-water interface. A plastic bag was then attached to the chamber for a measured amount of time, after which the bag was removed and the volume of water contained in the bag was measured. Change in volume during the time the bag was attached is the volumetric rate of flow (volume/time). The volumetric rate of flow was used to calculate flux velocity (distance/time), by dividing by the specific area of the seepage meter (Rosenberry and LaBaugh, 2008). The half-barrel drum used to calculate

U.S. Geological Survey staff taking discrete water-level measurements in preparation for nutrient sample collection, Bear Lake Muskegon County, Michigan.

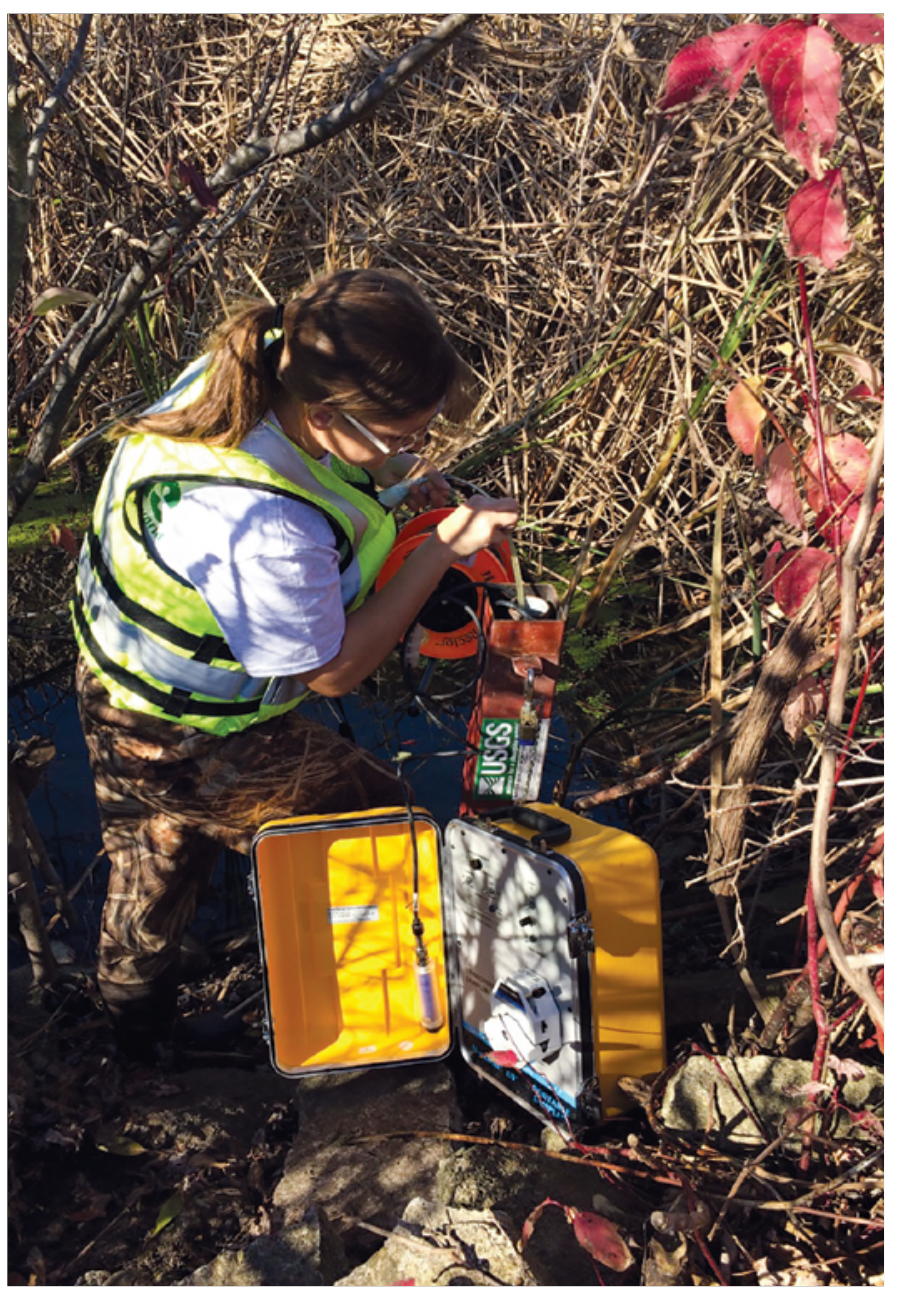


seepage had an area of approximately 2.70-square-foot. The change in volume over the time the seepage test was done is the volumetric flow rate of groundwater seepage. Positive numbers indicate flux velocity out of the unconfined aquifer (Willbrandt Pond West and Pond East) and negative numbers indicate a flux velocity into the confined aquifer. Specific coordinate locations of seepage measurements and flux velocity at each location are described in table 3. Seepage measurement data can be accessed from the USGS ScienceBase catalog website (Hoard and others, 2017).

Table 3. Flux measurement summary.

[Positive numbers indicate flux velocity out of the unconfined aquifer (Willbrandt Pond West and Pond East) and negative numbers indicate a flux velocity into the confined aquifer]

\begin{tabular}{cccc}
\hline $\begin{array}{c}\text { Measurement } \\
\text { number }\end{array}$ & $\begin{array}{c}\text { North } \\
\text { latitude }\end{array}$ & $\begin{array}{c}\text { West } \\
\text { longitude }\end{array}$ & $\begin{array}{c}\text { Seepage } \\
\text { (inch per day) }\end{array}$ \\
\hline 1 & 43.2655 & -86.2671 & -0.46 \\
\hline 2 & 43.2655 & -86.2669 & -0.05 \\
\hline 3 & 43.2657 & -86.2668 & 0.07 \\
\hline 4 & 43.2664 & -86.2658 & -0.36 \\
\hline 5 & 43.2678 & -86.2616 & 0.22 \\
\hline
\end{tabular}

\section{Water Chemistry Sampling}

During the 6-month sampling period, 12 samples were collected from all sample locations (fig. 2). An external handheld peristaltic pump with clean tubing was used to collect samples from all sample locations. Before each groundwater sample was taken, wells were purged of approximately three well volumes to obtain an accurate representation of local groundwater. Water-quality parameters (temperature, specific conductance, $\mathrm{pH}$, and dissolved oxygen) were recorded before sample collection and during well purging with a multiparameter water-quality sonde. Samples were collected in accordance with the USGS National Field Manual (U.S. Geological Survey, 2006). Samples were analyzed at the USGS National Water Quality Laboratory (NWQL) for schedules 2711 and 1571 that include ammonia, nitrite, nitrate, total nitrogen, phosphorus, phosphate, and chloride. Processing, filtering, and preservation of samples were done in the field following the USGS National Field Manual guidelines (U.S. Geological Survey, 2006). Robust Regression on Order Statistics (ROS) was used on all possible summary statistics involving constituent data, which compensated for below laboratory reported level data bias. Groundwater and surface-water quality data collected by USGS can be accessed from the NWIS database (U.S. Geological Survey, 2017).
Water quality sampling equipment at Well 4 Bear Lake, Muskegon County, Michigan.

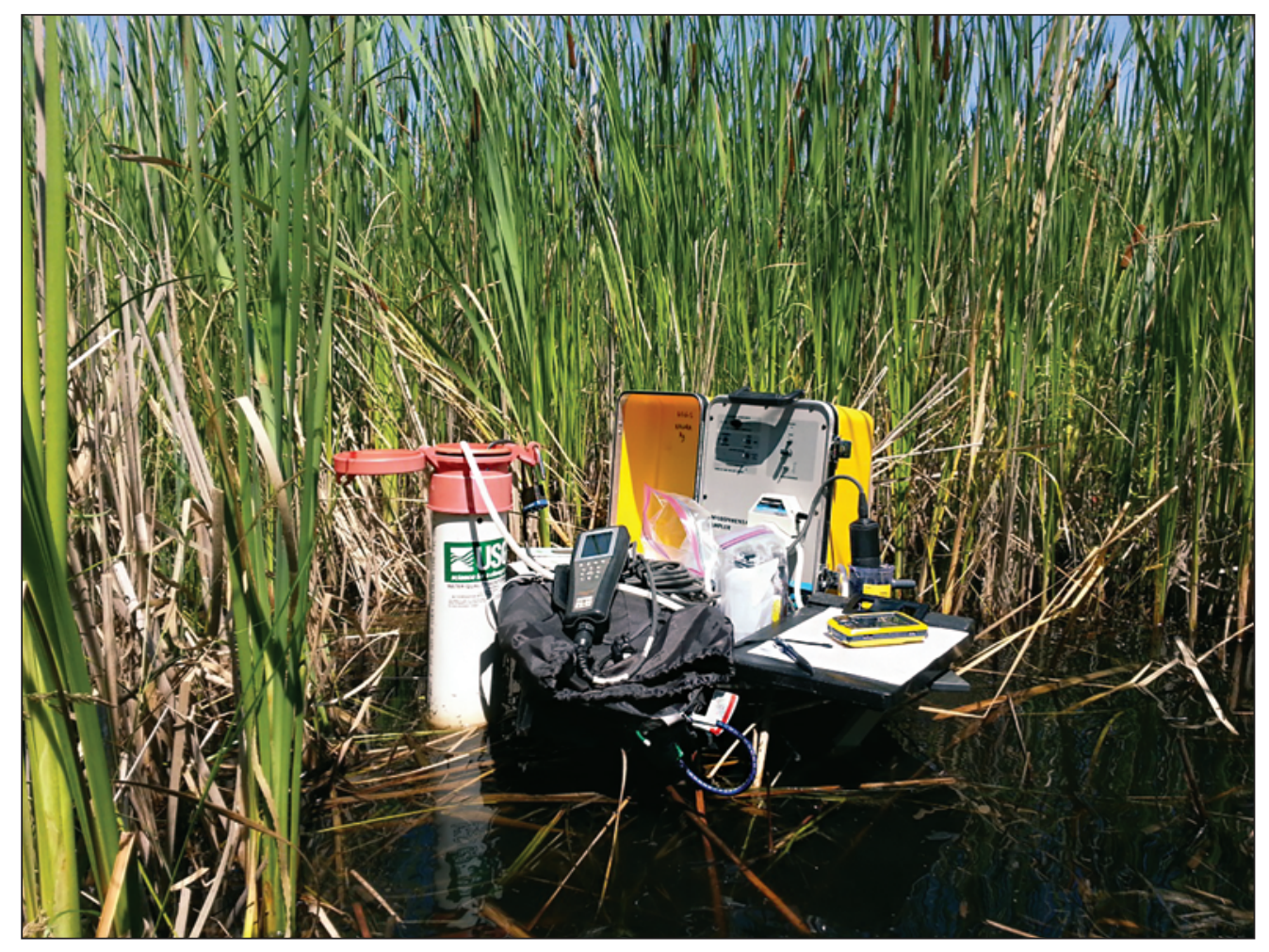




\section{Dupuit Flux Estimation}

Surface-water levels from Willbrandt Pond West, Bear Lake, and Bear Creek were used in combination with estimated water levels from Willbrandt Pond East to determine groundwater flux using the Dupuit equation (Rosenberry and LaBaugh, 2008). The Dupuit equation is for steady-state onedimensional flow and when applied to this system it responds rapidly to changes in head, which produces an instantaneous flux, and as such, an instantaneous load. Water elevations from Willbrandt Pond East are assumed to be similar to, but not the same as, Willbrandt Pond West because of the separation and location of both Pond West and East. Possible differences in water levels between Pond West and East were taken into account and an estimated load range is displayed with and without East Pond load contributions (table 5). The Dupuit equation for an unconfined aquifer is as follows:

$$
Q=K m \frac{\left(h_{1}^{2}-h_{2}^{2}\right)}{2 L}
$$

Where

$Q \quad$ is flux through vertical plane, in cubic feet per day;

$K \quad$ is horizontal hydraulic conductivity, in feet per day;

$m$ is length of the shoreline;

$h_{1} \quad$ is saturated aquifer thickness at the shoreline of the pond;

$h_{2} \quad$ is saturated aquifer thickness at Bear Lake or Bear Creek; and

$L \quad$ is the distance from Willbrandt Pond West and East to Bear Creek or Bear Lake.

Figure 3. Dupuit equation variable reference.

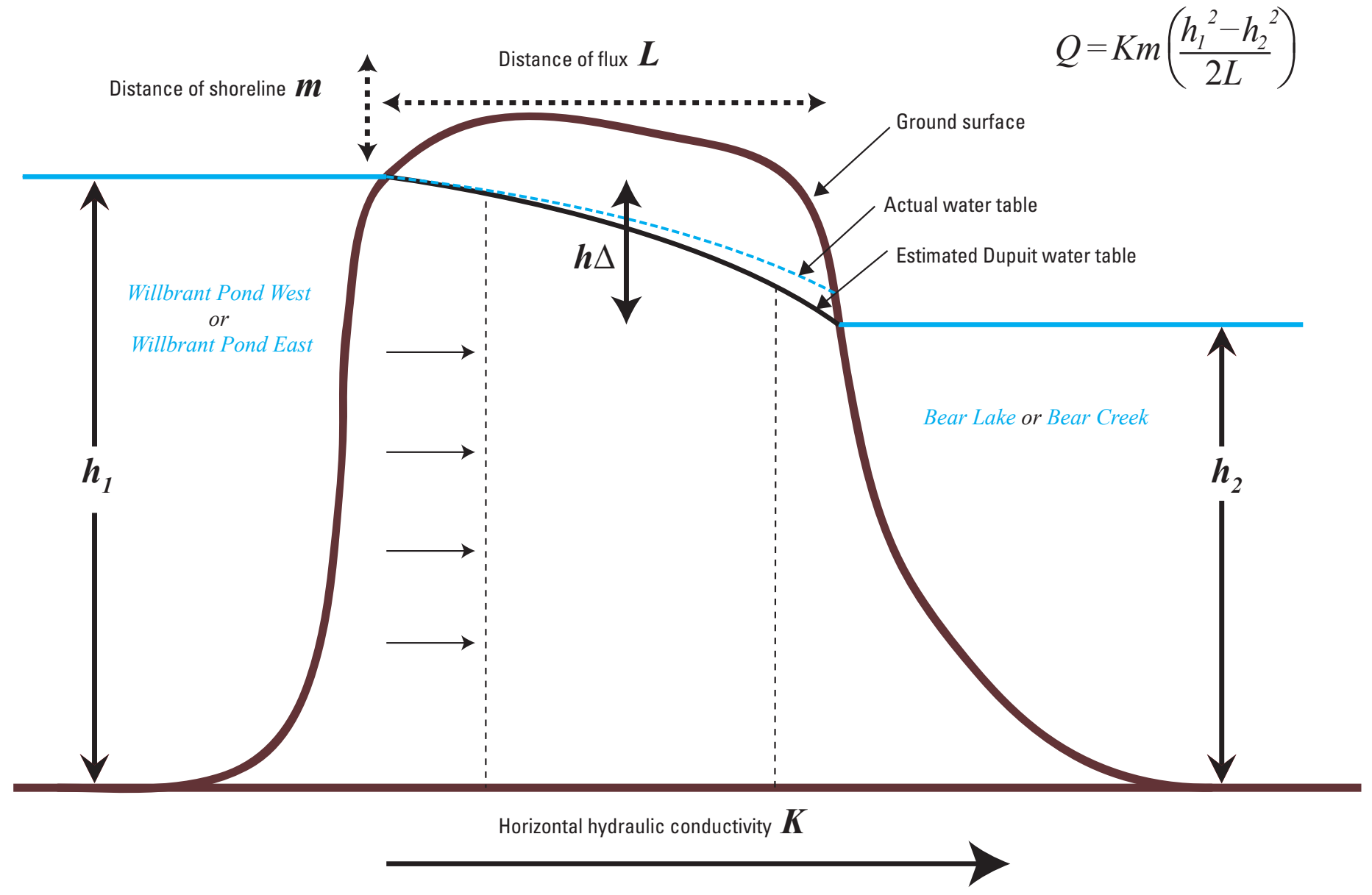


The hydraulic conductivity for the unconfined aquifer between the Willbrandt Ponds and Bear Lake was estimated to be an average of 0.33 foot per day based on general sediment content established during well installation (Driscoll, 1986). The length of shoreline and distance of the aquifer ( and was measured from aerial imagery using Google Earth (April 14, 2016, Muskegon, Mich., 43 15'55.67" North 86 15'51.09" West). Four areas were factored into the Dupuit equation to get the length of shoreline and aquifer distance. Area one was the shoreline on the northwest side of Willbrandt Pond East, area two is the west side of Willbrandt Pond West, area three is the south side of Willbrandt Pond West, and area four is the north end of Willbrandt Pond West. Nutrient concentrations from corresponding wells were applied to the Dupuit equation when calculating nutrient load. Saturated aquifer thickness was calculated by taking the difference between water levels of the Willbrandt Ponds and closest associated bodies of water (Bear Lake or Bear Creek). Values for and were calculated using 14,940 continuously recorded water-level measurements (every 15 minutes) for the 6-month study period. To obtain an un-inflated and , 567.58 value, a nominal unconfined aquifer reference depth of $12 \mathrm{ft}$ was used based on Bear Lake and Bear Creek depths. The value of was calculated every 15 minutes and summed to obtain a yearly flux. Methods for obtaining groundwater flux with the Dupuit equation were similar to those techniques used in the publication by Brennan and others (2015). A variable reference illustration is displayed to explain all of the variables used in the Dupuit nutrient calculations (fig. 3). A Monte Carlo themed approach was taken to establish if observed values calculated in the Dupuit equation fell within a 95-percent confidence interval of 1,000 pseudorandom realizations. One thousand realizations were developed based on observed values for each variable and standard error of equipment/analysis. A Monte Carlo simulation was developed for a fixed $K$ value and non-fixed $K$ with a standard deviation of 10 from the estimated value. Both fixed $K$ and non-fixed $K$ simulations fell within a 99-percent confidence interval produced by each simulation.

\section{Direct Seepage Flux Estimations}

Discrete seepage measurements were collected on October 6, 2015, along the berms of Willbrandt Ponds East and West in Bear Creek and were used in the calculation of direct seepage flux estimations. Positive seepage measurements were averaged to obtain an estimated direct seepage measurement, which was multiplied by estimated fluxing areas around Willbrandt Pond West and East to obtain a flux in cubic feet per year (table 5). The direct seepage method yielded an approximate 3,944,100 cubic feet per year flux, which is relatively close to the Dupuit estimation $(4,645,600$ cubic meters per year).

\section{Computation of Constituent Loads}

Annual loads were computed for total phosphorus, orthophosphate, total nitrogen, chloride, and ammonia. All groundwater nutrient and chloride loads using the Dupuit equation method were calculated by multiplying flux estimates by measured and interpolated nutrient concentrations. Periods of reverse flow were factored into the Dupuit equation, which means negative flux was added to the total annual load estimation. The total annual load of these constituents was calculated using the discrete nutrient values from Well 1, Well 2, Well 3, and Well 5 to produce a bilinear interpolation of each constituent concentration at 15-minute intervals. These 15-minute intervals were coincident with the flux estimates developed from the Dupuit assumption above. Interpolated concentration values were computed using the "zoo" package in R statistical programming language (Zeileis and Grothendieck, 2005). The interpolated concentration time series was then multiplied by corresponding flux time series estimated using the Dupuit equation. Load estimates from the 6-month sampling period were used to approximate an annual load in pounds per year.

Averaged discrete flux calculations and mean constituent concentrations were used in the calculation of discrete annual loads. A physical area was calculated for all four areas listed in the previous section and these areas were multiplied by direct seepage to obtain a discrete flux estimation. Constituent concentrations from closest groundwater wells were used in combination with local flux to obtain a seepage nutrient load. A Monte Carlo simulation was also produced for the direct seepage measurements and observed values fell outside the 95-percent confidence interval.

\section{Data-Quality Assurance}

Field blank and field replicate samples were collected on November 3, 2015, to determine if there was bias introduced with sampling equipment and field collection methods and to determine the environmental reproducibility of chemistry results. Most concentrations of constituents in blank samples were below (or near) the National Water Quality Laboratory (NWQL) reporting levels for all constituents. Field blank samples collected at Well 2 reported concentrations above the NWQL laboratory reporting level (0.010 milligram per liter $[\mathrm{mg} / \mathrm{L}])$ for ammonia $(0.0138 \mathrm{mg} / \mathrm{L})$. Well 4 field blank samples reported concentrations exceeding the reporting levels for ammonia $(0.0171 \mathrm{mg} / \mathrm{L})$ and nitrite $(0.0018 \mathrm{mg} / \mathrm{L}$; nitrite reporting level of $0.001 \mathrm{mg} / \mathrm{L}$ ). All replicate samples were determined to be within 5 percent of associated environmental samples. Blank and replicate samples demonstrated that field sample collection methods had little to no effect on observed constituent concentrations. Study results were not adjusted as a result. 


\section{Results}

\section{Water Levels}

Continuous water levels from Well 1, Well 3, Well 5, Willbrandt Pond West, and the Bear Lake site are summarized in figure 4. On average, Willbrandt Pond West had the highest water elevation and Bear Lake had the second lowest average surface-water elevation, which indicates that general surface-water and groundwater flow is from Willbrandt Pond West to Bear Lake. The water level at the Willbrandt Pond West remained stable in relation to groundwater and surfacewater levels throughout the 6-month study, which indicated a potentially static confined body of surface water. Water elevation in the wells typically ranged between Pond West elevation and Bear Lake elevation; however, transient spikes in groundwater elevation above Willbrandt Pond West elevations were observed. All sites except Pond West followed the same patterns of change in water elevations, which showed the immediate interaction between Bear Lake and surrounding groundwater. The lowest water elevation on average of all the sites was Well 3, which may indicate a seasonal fluctuation of groundwater from Bear Lake to Well 3. During mid-October, Well 3 shared similar water elevations to Bear Lake and Well 4 , which indicated a loss from the lake to groundwater in the area of Well 3. More data would need to be collected to confirm seasonal fluctuation of groundwater near Well 3. Due to equipment failure, sections of Well 3 and Well 4 water elevations are incomplete.

\section{Water Chemistry}

Water chemistry results collected from June to November 2015 are summarized by constituent and site in table 4. Bear Lake and Well 4 were the two most downgradient hydrologic features. Phosphorus and nitrogen are important nutrients used by all living things to create proteins and carry out important biological functions. In the right concentrations, phosphorus can promote healthy growth in an environment, but an imbalance can lead to negative environmental effects. Greater than $0.024 \mathrm{mg} / \mathrm{L}$ of phosphorus is indicative of eutrophic conditions in lakes (Carlson, 1977). Willbrandt Pond West had the greatest median value of total phosphorus $(1.09 \mathrm{mg} / \mathrm{L})$ of all sites studied, which indicated that the Pond West is, on average, highly eutrophic. The groundwater connection of Willbrandt Pond West to Bear Lake indicates that Pond West is a potential source of phosphorus loading to Bear Lake.

The nitrogen cycle plays an important part in biological growth and decay. Imbalance in the nitrogen cycle could indicate a more active portion of the environment (Brennan and others, 2015). Well 2 had the greatest median value of total nitrogen $(6.67 \mathrm{mg} / \mathrm{L})$ and ammonia $(5.51 \mathrm{mg} / \mathrm{L})$; however, there may be high levels of organic decay prompting increased ammonia concentrations in that area. Summary statistics include estimated values, and a Robust ROS method was applied to all possible values below laboratory reporting limits.

Chloride is considered to be a conservative ion when analyzed in the environment. When chloride is bound chemically in the environment, particulate has very little effect on the concentrations of chloride (Mullaney and others, 2009). These chemical properties make it a good environmental point source indicator of water quality. Concentrations of chloride in Willbrandt Pond West on average $(118.4 \mathrm{mg} / \mathrm{L})$ were approximately double the average of Bear Lake $(46.6 \mathrm{mg} / \mathrm{L})$. Average chloride concentrations in all of the wells except Well 4 and Well 3 were between averages of Pond West and Bear Lake, which indicates that Pond West is a potential source of both nutrients and chloride to Bear Lake.

\section{Groundwater Nutrient Loads}

The summary of the directly measured flux from five discrete locations along the northwest berm of Willbrandt Pond West and East is presented in table 3. Sites were chosen based on soil composition and capability of making seepage measurements. Negative fluxes in the seepage measurements were not included in the nutrient load calculations. Nutrient concentrations in groundwater on average were greater than Bear Lake concentrations. As a result, negative fluxes in the seepage measurements were not included in the nutrient load calculations.

A comparison of the annual loads for total phosphorus, orthophosphate, total nitrogen, chloride, and ammonia with both Dupuit and direct seepage methods are presented in table 5 . Both methods for calculating flux represent a likely range of constituent loads to Bear Lake. Direct seepage was taken short term over a period of a day, but continuous measurements used in the Dupuit equation were taken over 6 months. The dataset collected for the Dupuit equation was significantly greater than the dataset collected for the direct seepage load, making the Dupuit equation more robust. The Dupuit equation yielded an estimated 4,645,600 cubic feet per year flux from Willbrandt Ponds to Bear Lake while the discrete flux equation yielded 3,944,100 cubic feet per year. Nutrient loading was calculated using the discrete flux measurements and resulted in 110 pounds per year of phosphorus, 80 pounds per year of orthophosphate as phosphorus, 460 pounds per year of nitrogen, 25,500 pounds per year of chloride, and 300 pounds per year of ammonia as nitrogen (table 5). 


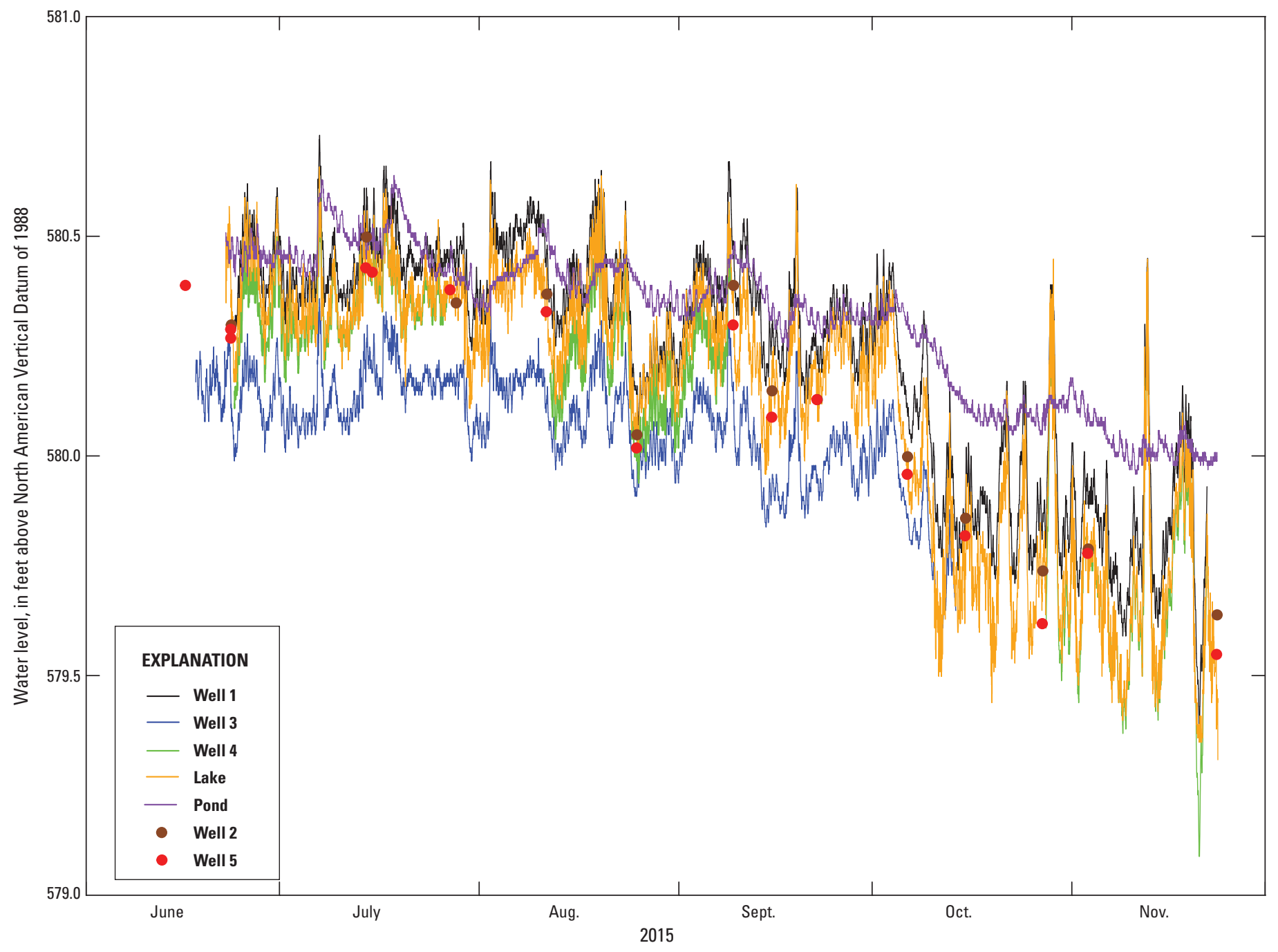

Figure 4. Continuous water levels in feet above North American Vertical Datum of 1988 (NAVD 88). 
Table 4. Summary statistics of constituent concentrations by sampling site.

[Site, site name; Site ID, identification; n, number of samples; mg/L, milligram per liter; STDEV, standard deviation; LRL, laboratory reporting level; <, less than; ROS, Regression on Order Statistics]

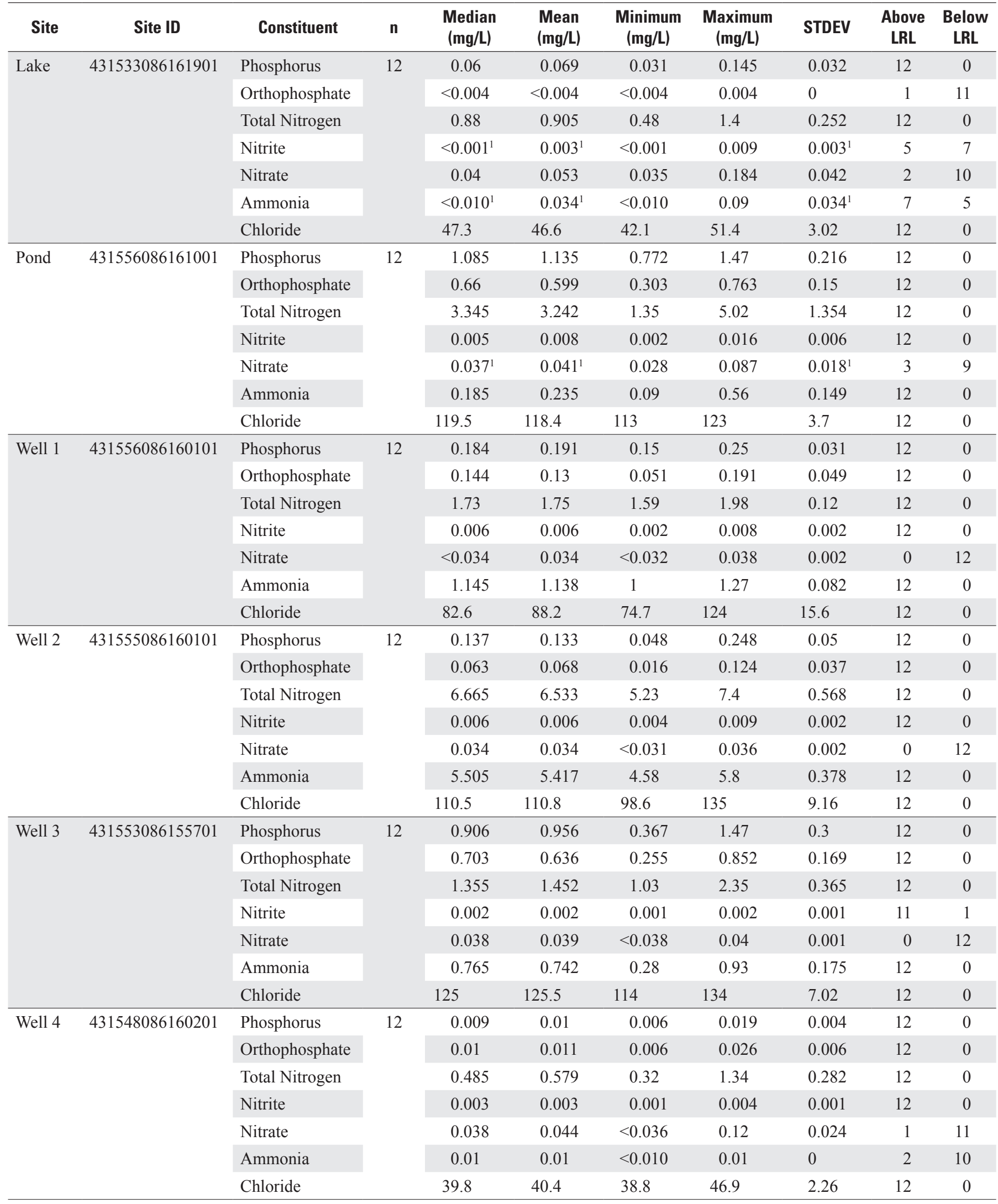


Table 4. Summary statistics of constituent concentrations by sampling site.-Continued

[Site, site name; Site ID, identification; n, number of samples; mg/L, milligram per liter; STDEV, standard deviation; LRL, laboratory reporting level; <, less than; ROS, Regression on Order Statistics]

\begin{tabular}{|c|c|c|c|c|c|c|c|c|c|c|}
\hline Site & Site ID & Constituent & n & $\begin{array}{l}\text { Median } \\
\text { (mg/L) }\end{array}$ & $\begin{array}{l}\text { Mean } \\
\text { (mg/L) }\end{array}$ & $\begin{array}{c}\text { Minimum } \\
\text { (mg/L) }\end{array}$ & $\begin{array}{c}\text { Maximum } \\
\text { (mg/L) }\end{array}$ & STDEV & $\begin{array}{c}\text { Above } \\
\text { LRL }\end{array}$ & $\begin{array}{c}\text { Below } \\
\text { LRL }\end{array}$ \\
\hline \multirow[t]{4}{*}{ Well 5} & \multirow[t]{4}{*}{431604086154201} & Phosphorus & \multirow[t]{4}{*}{12} & 0.362 & 0.374 & 0.192 & 0.591 & 0.104 & 12 & 0 \\
\hline & & Total nitrogen & & 3.65 & 3.637 & 3.13 & 4.2 & 0.283 & 12 & 0 \\
\hline & & Nitrite & & 0.004 & 0.004 & 0.001 & 0.006 & 0.001 & 12 & 0 \\
\hline & & Chloride & & 119 & 118.7 & 112 & 129 & 4.75 & 12 & 0 \\
\hline
\end{tabular}

${ }^{1}$ Robust ROS methods were applied to all possible constituent summary statistics.

Table 5. Method comparison of the total annual flux (cubic feet per year) and annual constituent load (pounds per year).

[All observed values calculated using the Dupuit equation fall within a 99-percent confidence interval established by the Monte Carlo simulation. Direct seepage calculations fall outside of the 95-percent confidence interval established by the Monte Carlo simulation]

\begin{tabular}{lcccccc}
\hline \multicolumn{1}{c|}{ Method } & $\begin{array}{c}\text { Total flux } \\
\text { (cubic feet } \\
\text { per year) }\end{array}$ & $\begin{array}{c}\text { Total } \\
\text { phosphorus } \\
\text { (pounds per } \\
\text { year) }\end{array}$ & $\begin{array}{c}\text { Ortho- } \\
\text { phosphate } \\
\text { (pounds per } \\
\text { year) }\end{array}$ & $\begin{array}{c}\text { Total } \\
\text { nitrogen } \\
\text { (pounds per } \\
\text { year) }\end{array}$ & $\begin{array}{c}\text { Chloride } \\
\text { (pounds per } \\
\text { year) }\end{array}$ & $\begin{array}{c}\text { Ammonia } \\
\text { (pounds per } \\
\text { year) }\end{array}$ \\
\hline $\begin{array}{l}\text { Dupuit flux and interpolated concentrations } \\
\begin{array}{l}\text { Seepage meter flux and single day average } \\
\text { measured concentrations }\end{array}\end{array}$ & $4,645,600$ & $60-130$ & $40-100$ & $200-830$ & $12,700-32,100$ & $130-670$ \\
\hline
\end{tabular}

\section{Constituent Concentration Comparison}

Constituent concentration averages from this study were compared to the USGS National Water-Quality Assessment (NAWQA) and State of Michigan concentration averages in table 6. Groundwater and surface-water concentrations from this study were compared to USGS NAWQA groundwater (USGS, 1999) and State of Michigan groundwater and stream water concentrations (Hoard and others, 2009). Median phosphorus concentrations in groundwater from the current (2017) study were approximately 19 times greater than previously reported median groundwater concentrations in Michigan (Cummings, 1989). Median orthophosphate concentrations from the current study were at least 11 times greater than previously reported mean orthophosphate concentrations in groundwater from Michigan (Cummings, 1989). Median total nitrogen, ammonia, and nitrate plus nitrite concentrations from groundwater in the current study were 5.7 times, 14.4 times, and 1.8 times greater, respectively, than State of Michigan median concentrations (Cummings, 1989); however, mean nitrate plus nitrite concentrations in groundwater from the current study were 53.6 percent less than the national mean nitrate plus nitrite concentration in groundwater (USGS, 1999). Phosphorus concentrations in Willbrandt Pond West were 21 times greater than the State of Michigan surface-water means. Although the comparison is between the stagnant West Pond and the well-mixed streams of Michigan, the difference in concentrations is still large. In addition, the groundwater nutrient concentrations from this study (except for nitrate plus nitrite) are higher than USGS NAWQA (USGS, 1999) and State of Michigan average concentrations. 
Table 6. Comparison of study observations with previously reported national and regional observations.

[NAWQA, National Water Quality Assessment; USGS, U.S. Geological Survey; mg/L, milligram per liter; P, phosphorus; na, not available from this study; $<$, less than; N, nitrogen]

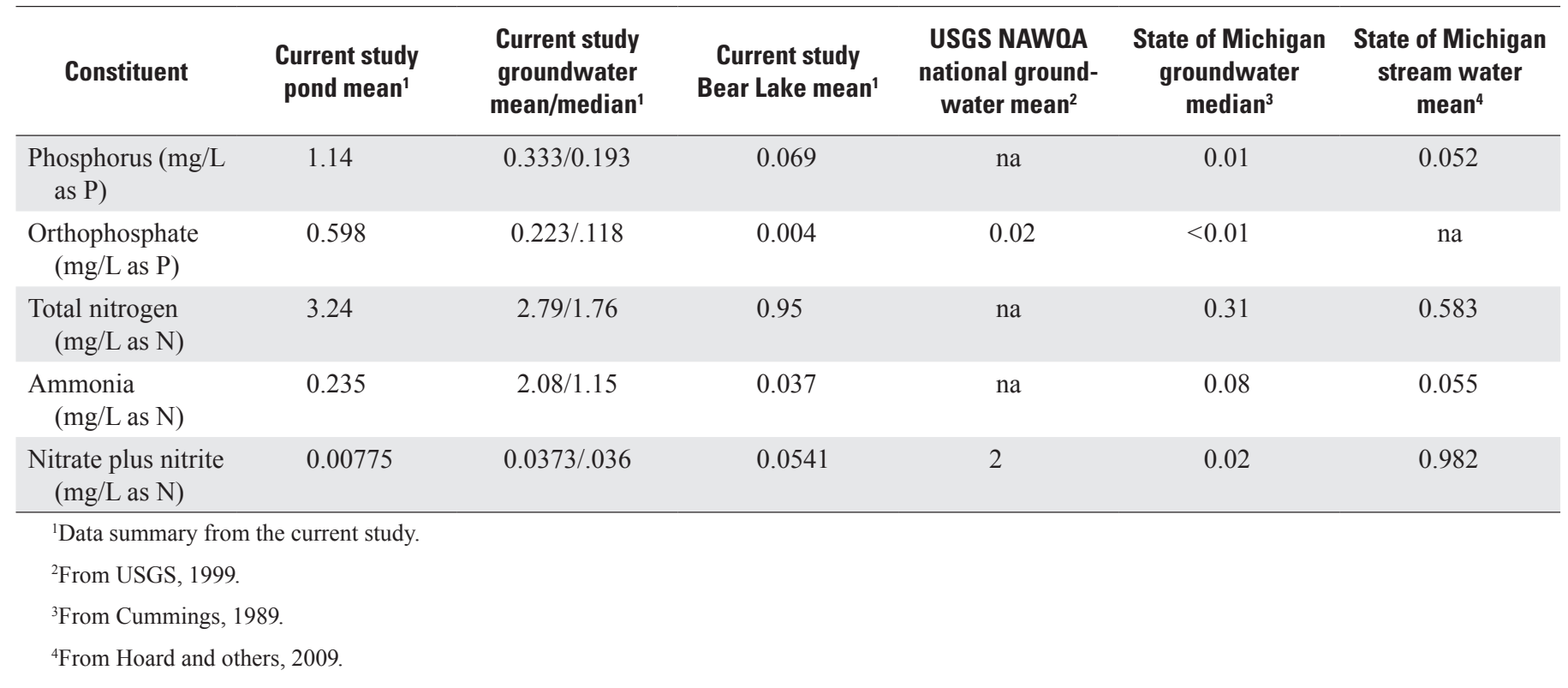

\section{Phosphorus Loads}

In 2008, the MDEQ calculated the internal and external phosphorus load of Bear Lake, and in 2015, AWRI did a study to further update the internal phosphorus loading in Bear Lake (MDEQ, 2008; AWRI, 2014). These data were used in conjunction with data from this current study to update the mass balance for total phosphorus in Bear Lake. Annual phosphorus loads were calculated using the Dupuit equation as well as direct seepage measurements collected as part of this study, and data are presented in table 5. A current phosphorus load has been established using shallow groundwater loads from this study and phosphorus loads from previous studies (AWRI, 2015; MDEQ, 2008). The MDEQ calculated an initial internal and external phosphorus load (total 3,387 lb/yr) for Bear Lake in 2008, which indicated about one-half of phosphorus loading was external, mostly from Bear Creek (45 percent), and about one-half was internal (46 percent) (MDEQ, 2008). A total phosphorus load from MDEQ's study is shown in figure 5A. Later in 2014, AWRI updated the internal phosphorus calculations to better represent internal load by sampling total phosphorus in sediment from multiple locations in Bear Lake (AWRI, 2014). Phosphorus loads from MDEQ and AWRI were combined to make an updated phosphorus load in Bear Lake (fig. 5B). The current phosphorus load displays the contribution of shallow groundwater from Willbrandt Pond East and West using Dupuit and direct seepage calculations (fig. 5C). Dupuit equation method and direct seepage loads were incorporated into the updated phosphorus load to show a current phosphorus load (fig. 5D). Considering the current phosphorus budget, there is still 16-19 percent of the phosphorus load unaccounted for in Bear Lake. 
Total phosphorus load represented in each pie chart is 3,387 pounds per year
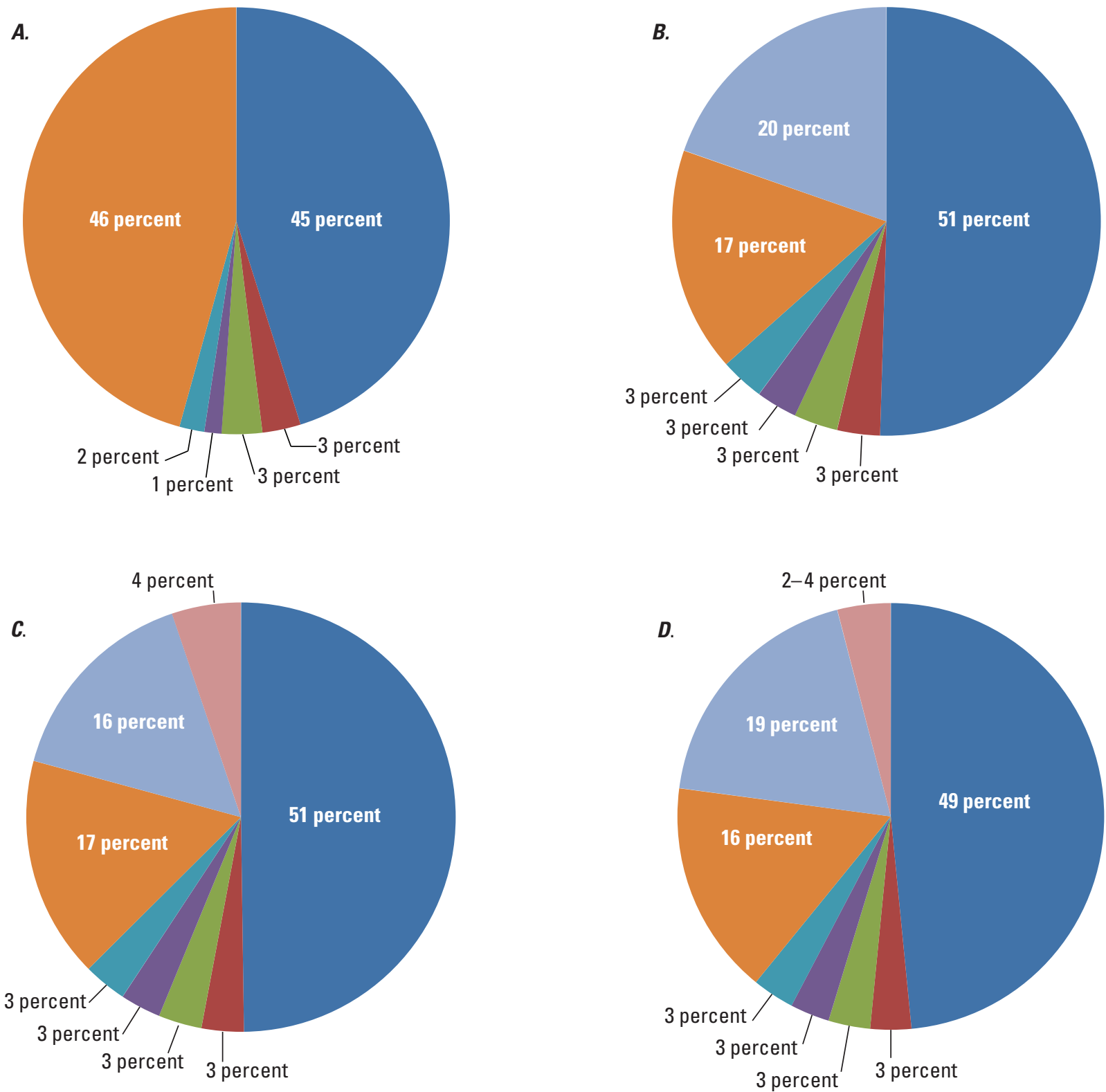

\section{EXPLANATION}
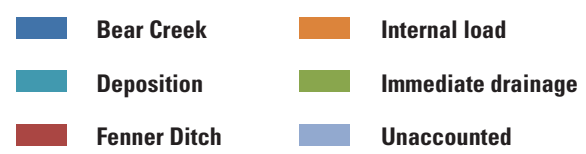

Septic (estimated)

Shallow groundwater

Unaccounted

Figure 5. Phosphorus load of Bear Lake based on Michigan Department of Environmental Quality (MDEQ) initial estimations and updated estimations by Annis Water Resource Institute (AWRI) and U.S. Geological Survey (USGS). A, The initial estimated phosphorus load of Bear Lake established by the MDEO in 2008. B, MDEQ's initial phosphorus load estimation of Bear Lake with an updated internal load by AWRI in 2015. C, Updated phosphorus load including USGS estimation of shallow groundwater phosphorus load estimated with discrete seepage measurements. $D$, Updated phosphorus load including USGS estimation of shallow groundwater phosphorus load estimated with the Dupuit equation. 


\section{Summary and Conclusions}

The Willbrandt Ponds study area consists of two manmade earthen berm retention ponds (Willbrandt Ponds East and West) on the northeast end of Bear Lake in North Muskegon, Michigan, in Muskegon County. Studies conducted by the State of Michigan and Grand Valley State University revised initial internal phosphorus load estimates and indicated an imbalance in the phosphorus budget in Bear Lake. From June 2015 through November 2015, the U.S. Geological Survey conducted an investigative study to quantify the load of nutrients from shallow groundwater around the Willbrandt Ponds in an effort to update the phosphorus load into Bear Lake. Seven sampling sites were established, including two surface-water sites and five shallow groundwater wells, in the pond study area and Bear Lake. Twelve samples were collected at each site. Water quality data from the 12 samples taken were used in loading calculations and statistical comparison to national and Michigan data. Continuous (15-minute interval) water-level measurements were collected at Pond West, Bear Lake, Well 1, Well 3, and Well 4. Discrete waterlevel measurements were made before and after purging and sampling wells. Discrete groundwater flux measurements were made on October 6, 2015, at five locations along Pond West and Pond East. Data obtained from these measurements and samples were used to assess the annual flux of groundwater and the annual load of nutrients from shallow groundwater into Bear Lake.

Analysis of water levels showed that on average Willbrandt Pond West had the highest water-level elevation and Bear Lake had the second lowest average water elevation, which indicated that the general flow of water was from Willbrandt Pond West to Bear Lake. Water elevation in the wells typically ranged between Pond West elevation and Bear Lake elevation; however, transient spikes in groundwater elevation above Willbrandt Pond West elevations were observed.

Median phosphorus concentrations in groundwater from the current study were an order of magnitude greater than previously reported median groundwater concentrations in Michigan. Median orthophosphate concentrations from the current study were also greater than previously reported mean orthophosphate concentrations in groundwater from Michigan. Concentrations of nitrogen constituents were compared between the current study and values obtained from Michigan and the Nation. Median total nitrogen, ammonia, and nitrate plus nitrite concentrations from groundwater in the current study were all greater than State of Michigan median concentrations; however, mean nitrate plus nitrite concentrations in groundwater from the current study were about one-half that of the national mean nitrate plus nitrite concentration in groundwater.
Computations using the Dupuit equation for steady-state flow in an unconfined aquifer of water-level measurements in the Pond West and Bear Lake sites resulted in an estimated annual groundwater flux of 4,645,600 cubic feet annually. The estimated annual nutrient loads using the Dupuit equation were $60-130$ pounds per year of phosphorus, $40-100$ pounds per year of orthophosphate as phosphorus, $200-830$ pounds per year of nitrogen, 12,700-32,100 pounds per year of chloride, and 130-670 pounds per year of ammonia as nitrogen.

Computations using seepage measurements from halfbarrel seepage meters on October 6, 2015 at five locations around the Willbrandt Ponds resulted in an estimated annual groundwater flux of 3,944,070 cubic feet annually. Nutrient loading was calculated using the discrete flux measurements and resulted in 110 pounds per year of phosphorus, 80 pounds per year of orthophosphate, 460 pounds per year of nitrogen, 25,500 pounds per year of chloride, and 300 pounds per year of ammonia. Both estimates used in this study (Dupuit and direct seepage) were within a close range of each other, which confirmed general accuracy of load estimates. The actual load of each constituent likely falls within the range of values.

Previous studies of this area have been particularly focused on phosphorus loading that drives the Muskegon Lake area of concern (AOC) eutrophication beneficial use impairment. Based on the current study, the likely range of phosphorus being delivered from shallow groundwater to Bear Lake is between 110 and 130 pounds of phosphorus per year, which represents 4 percent of the previously reported annual phosphorus load to Bear Lake. No chemical balance comparisons can be made for total nitrogen, ammonia, or chloride loads because they have not been previously investigated at Bear Lake.

This research has helped refine the nutrient balance estimated to Bear Lake, a component of the Muskegon Lake area of concern. The information provided can inform management decisions for prioritizing actions to improve the water quality and lead to delisting beneficial use impairments for this area.

\section{Limitations}

This study was done during a 6-month span, but annual collection of water levels and nutrient concentrations would further refine nutrient loads into Bear Lake and would provide more accuracy to shallow groundwater load estimations used in this study (Dupuit equation). Also, additional seepage and piezometer measurements would be beneficial in estimating groundwater flux in this area. An additional surface-water site on Willbrandt Pond East would also help in determining the nutrient loading from Pond East to Bear Lake. 


\section{References Cited}

Brennan, A.K., Hoard, C.J., Duris, J.W., Ogdahl, M.E., and Steinman, A.D., 2015, Water quality and hydrology of Silver Lake, Oceana County, Michigan, with emphasis on lake response to nutrient loading, 2012-14: U.S. Geological Survey Scientific Investigations Report 2015-5158, 75 p., accessed 3/12/2016 at http://dx.doi. org/10.3133/sir20155158.

Carlson, R.E., 1977, A trophic state index for lakes: Limnology and Oceanography, v. 22, p. 361-369.

Cummings, R.T., 1989, Natural ground-water quality in Michigan, 1974-87: U.S. Geological Survey Open-File Report 89-259, $50 \mathrm{p}$.

Cunningham, W.L., and Schalk, C.W., comps., 2011, Groundwater technical procedures of the U.S. Geological Survey: U.S. Geological Survey Techniques and Methods, book 1, chap. A1, 151 p., accessed 5/20/2017 at http://pubs.usgs. gov/tm/1a1/.

Driscoll, F.G., 1986, Groundwater and wells (2d ed.): St. Paul, Minnesota Johnson Screens, 75 p.

Hoard, C.J., Fuller, L.M., and Fogarty, L.R., 2009, Analysis of water-quality trends for selected streams in the Water Chemistry Monitoring Program, Michigan, 1998-2005: U.S. Geological Survey Scientific Investigations Report 2009-5216, 48 p.

Hoard, C.J., Maurer, J.A., Totten, A.R., and Duris, J.W., 2017, Groundwater seepage measurements in northeast section of Bear Lake, Muskegon County, Michigan, October 2015: U.S. Geological Survey data release, accessed September 2017 at https://doi.org/10.5066/F73J3BVJ.

LeSage, S., and Smith, J., 2008, Water quality and pollution control in Michigan 2008 Sections 303(d), 305(b), and 314 Integrated Report: Michigan Department of Environmental Quality Report \#MI/DEQ/WB-06/019, 118 p.

National Oceanic and Atmospheric Administration [NOAA], 2015, Great Lakes Environmental Research Laboratory data system: NOAA database, accessed 05-13-2015 at https:// www.glerl.noaa.gov//metdata/mkg/archive $/ \mathrm{mkg} 2015.05$ t.txt.

Michigan Department of Environmental Quality [MDEQ], 2011, Stage 2 Remedial Action Plan Muskegon Lake area of concern: Office of the Great Lakes, Great Lakes Management Unit, Michigan Department of Environmental Quality, 19 p.

Michigan Department of Environmental Quality [MDEQ], 2008, Total maximum daily load for phosphorus for Bear Lake, Muskegon County: Lansing, Michigan, Michigan Department of Environmental Quality, Water Bureau, 27 p.
Mullaney, J.R., 2015, Evaluation of the effects of sewering on nitrogen loads to the Niantic River, southeastern Connecticut, 2005-11: U.S. Geological Survey Scientific Investigations Report 2015-5011, 30 p., accessed 2/17/2017 at http://dx.doi.org/10.3133/sir20155011.

Mullaney, J.R., Lorenz, D.L., Arntson, A.D., 2009, Chloride in groundwater and surface water in areas underlain by the glacial aquifer system, northern United States: U.S. Geological Survey Scientific Investigations Report 2009-5086, $41 \mathrm{p}$.

Robertson, D.M., Garn, H.S., Rose, W.J., Juckem, P.F., and Reneau, P.C., 2012, Hydrology, water quality, and response to simulated changes in phosphorus loading of Mercer Lake, Iron County, Wisconsin, with emphasis on effects of wastewater discharges on water quality: U.S. Geological Survey Scientific Investigations Report 2012-5134, 58 p.

Rosenberry, D.O., and LaBaugh, J.W., 2008, Field techniques for estimating water fluxes between surface water and ground water: U.S. Geological Survey Techniques and Methods, book 4, chap. D2, 128 p.

Smit, J.T., and Steinman, A.D., 2014, Wetland sediment phosphorus flux in response to proposed hydrologic reconnection and warming: Wetlands, v. 35, no. 4, 107 p.

Steinman, A.D., and Ogdahl, M.E., 2015, (AWRI) TMDL reevaluation-Reconciling internal phosphorus load reductions in a eutrophic lake: Lake and Reservoir Management, v. 31 , no. 2 , p.115-126.

U.S. Geological Survey [USGS], variously dated, National field manual for the collection of water-quality data: U.S. Geological Survey Techniques of Water-Resources Investigations, book 9, chaps. A1-A10 [variously paged]. [Also available at http://pubs.water.usgs.gov/twri9A.]

U.S. Geological Survey [USGS], 1999, The quality of our nation's waters-Nutrients and pesticides: U.S. Geological Survey Circular 1225, $82 \mathrm{p}$.

U.S. Geological Survey [USGS], 2006, Collection of water samples (ver. 2.0): U.S. Geological Survey Techniques of Water-Resources Investigations, book 9, chap. A4, 231 p., accessed 3/12/16 at http://pubs.water.usgs.gov/twri9A4/.

U.S. Geological Survey [USGS], 2017, National Water Information System (NWISWeb): U.S. Geological Survey database, accessed 3/12/2017 at http://waterdata.usgs.gov/nwis.

Zeileis, A., and Grothendieck, G., 2005, Zoo-S3 infrastructure for regular and irregular time series. Journal of Statistical Software, v. 14, no. 6, p. 1-27, accessed 3/12/2017 at http://www.jstatsoft.org/v14/i06/. 
Director, Upper Midwest Water Science Center U.S. Geological Survey

6520 Mercantile Way

Suite 5

Lansing, MI 4891

Publishing support was provided by the Madison and Rolla units of the USGS Science Publishing Network. 
